\title{
Chemical Composition of Seed Enterolobium cyclocarpum (Jacq.) Griseb from Jalisco, México
}

\section{J Jesús Vargas-Radilloㅁ, Rubén Rosales Ramírez ${ }^{2}$ and Lucía Barrientos Ramírez ${ }^{1 *}$}

${ }^{1}$ Department of Wood, Pulp and Paper, University Center for Exact Sciences and Engineering, University of Guadalajara, Las Agujas, Mexico

${ }^{2}$ Department of Animal Production, Veterinary Medicine and Zootechnics,

University Center for Biological and Agricultural Sciences, Universidad de

Guadalajara, Mexico

*Corresponding Author: Lucía Barrientos Ramírez, Department of Wood, Pulp and Paper, University Center for Exact Sciences and Engineering, University of Guadalajara, Las Agujas, Mexico.
Received: April 15, 2021

Published: April 17, 2021

(C) All rights are reserved by Lucía Barrientos

Ramírez., et al.

\begin{abstract}
Mature seeds of Enterolobium cyclocarpum were sampled from two locations with physiographic and edaphoclimatic differences, in the state of Jalisco, México. The ground seeds of E. cyclocarpum was then analyzed. Nutritional value was evaluated by proximate analysis; amino acids by HPLC; and minerals through absorption spectrophotometry. Different nutritional value was obtained in each sampled locality. In particular crude proteins was high, with 19.56 and 30.34 (g/100 g dm) in each of the sampling areas. Alike, the aminoacids content showed variation by sampling area, although in most cases, higher value than the daily requirements suggested in the amino acid scoring patterns from the FAO/WHO/ONU reports. In terms of the mineral content of phosphorus, potassium, magnesium, sodium, copper, showed difference between both sampling sites, which appear to be directly related to the quality of the sandy loamy.
\end{abstract}

Keywords: Seeds; Amino Acids; Crude Protein; Minerals, Soil

\section{Abbreviations}

EE: Ether Extract; CP: Crude Protein; CF: Crude Fibre; AOAC: Association of Official Agricultural Chemists; NFE: Nitrogen Free Extracts; OPA; O-phthalaldehyde; AAS: Atomic Absorption Spectrophotometry; WHO: World Health Organization

\section{Introduction}

Mexico is one of the countries with the highest number of animal and plant species, which means that it is among the "megadiverse" countries, with 60 and 70 percent of the known diversity of the planet. The great ecological variability and the complex topography and geology of Mexico, climates and microclimates, produce diverse and multiple ecosystems) [1]. Enterolobium cyclocarpum (Jacq.) Griseb. (Leguminosae), known in Mexico and Central America as parota, guanacaxtle or conacaste, family Fabaceae. Is native to the tropical regions of the Americas including Brazil, Colombia, Mexico, and Venezuela [2].

It is a tree up to $30 \mathrm{~m}$ tall, with a diameter of 1-3 m, with Pods 7 to $12 \mathrm{~cm}$ in diameter, flattened and curled, woody, dark brown, shiny, sweet smell and taste, containing numerous ovoid and flattened seeds, $2.3 \times 1.5 \mathrm{~cm}$ brown and shiny with a pale line with the shape of the contour of the seed, surrounded by a fibrous and sweet Pulp with an annual production of around $700 \mathrm{~kg}$ of seed per tree. This fruits (pods with its seeds) come off the trees and 
consumed by grazing ruminants, but most of seeds are completely excreted due to the protection of the cuticle that surrounds them, being this the main form of propagation of this plant. Cooked poods (higher bioavailability) can be used by monogastric animals. The forage use of this species occurs especially in the dry season, when the availability of grass-type forage is scarce, so the use of arboreal species is used as a source of food for livestock [3-6].

Since legume seeds have a high nutritional value, they are used as a source of protein, amino acids, minerals, vitamins, fatty acids, oligosaccharides and fiber, among others compounds [7,8], so, they are collected by men for intake, and also for animals in field for feed [9]. It also contains a high value in sugars (6\%), Fe, Ca, P and ascorbic acid, while the almond, integument and the pod itself present together up to $44 \%$ protein, a value comparable to that of soybeans animals [5].

This tree, due to its great biomass and foliage, result in large amount of fodder in soil, and thus carbon pools, that favors the growth of other plants that serve as pasture for cattle feed [9]. Its habitat is found at altitudes of 0 - 942 m.s.n.m., temperatures of $22.3-26.9^{\circ} \mathrm{C}$ and rainfall of $860-2600 \mathrm{~mm}$, in various types of soil [10].

E. cyclocarpum leaves are less acceptable by ruminants due to their high contents of anti-nutritional factors, despite its acceptable crude protein content of 15.59 - 48.2\% [11,12].

The objective of this study was to determine the nutritional elements of mature parota seeds, such as crude protein, minerals and amino acids, in 2 localities with biogeographic differences named Tequila and Autlan, located in the state of Jalisco, central western Mexico, with the purpose of comparing their nutritional content.

\section{Aim of the Study}

This work aims to provide information on the importance of environmental conditions on plant properties, especially nutritional ones, for foodstuffs and also as to protein-balance forage diets for cattle.

\section{Materials and Methods}

Place of study

The sampling sites of this study are located in the state of Jalisco (Central-West Mexico); Autlán, southwest of the state $\left(19^{\circ} 46^{\prime} 00^{\prime \prime} \mathrm{N}\right.$ $\left.104^{\circ} 22^{\prime} 00^{\prime \prime} \mathrm{W}\right)$ and Tequila, center-north of the state $\left(20^{\circ} 52^{\prime} 46^{\prime \prime} \mathrm{N}\right.$ $103^{\circ} 50^{\prime} 08^{\prime \prime} \mathrm{W}$ ). The altitude, geographic and climatic characteristics of these localities contrast significantly (Table 1).

In the field stage, tours were made in the physiographic areas in the months of May and June, the time of greatest fruiting, when the pods ripen and detach from the tree easily. During the tours, the botanical samples and the pods were collected in a mature state, taking random fruits from 10 trees $(n=10)$, in different areas of the crown, for a sample of approximately $5 \mathrm{~kg}$ of pods. The seeds were extracted manually and a composite sample of approximately $1 \mathrm{~kg}$ was formed. The seeds obtained from the fruit were washed in distilled water and dried at 55-60 ${ }^{\circ} \mathrm{C}$ for $48 \mathrm{~h}$ in an oven with forced air circulation. After drying, the seeds were ground and passed through a $0.5 \mathrm{~mm}$ mesh sieve [13]. They were kept refrigerated for analysis.

Soil sampling was carried out at a depth of $15 \mathrm{~cm}$, for the corresponding physical and chemical analyses.

Chemical composition and nutritional evaluation of Enterolobium

First, the seed flour was degreasing with cold hexane at $4^{\circ} \mathrm{C}$. after this, was applied centrifugation for $30 \mathrm{~min}$, and then was evaporated the methanol until the material was dry [14]. Proximate composition: crude protein (CP) (\% N x 6.25), crude fiber (CF), ether extract (EE or fatty compounds), moisture, ash and carbohydrates (or Nitrogen free extract, NFE, calculated by difference) were determined following standardized techniques [13].

Amino acid analysis

Samples were hydrolyzed with $6 \mathrm{~N} \mathrm{HCl}$ at $105^{\circ} \mathrm{C}$ for $24 \mathrm{~h}$. They were then neutralized with $6 \mathrm{~N} \mathrm{NaOH}$ and filtered to remove solids., Analysis was carried out by reversed phase (C18 column) HPLC (Varian) with fluorescence detection, and precolumn derivatization with 0-phthalaldehyde (OPA) [15].

\section{Mineral composition}

Analyses of macrominerals and microminerals in soils and seeds were performed by atomic absorption spectrophotometry (Perkin-Elmer spectrophotometer) [16].

In all analyses, three repetitions were made $(n=3)$. The mean ( and standard deviation (sd) are reported. 


\section{Results and Discussion}

The following tables present the results of the sampling locations, Autlan and Tequila. Table 1 shows geographic and environmental data. Altitude very contrasting of 500 to 1,200 m.s.n.m. Likewise the temperature is similar in the 2 locations. Rainfall is very different since in Tequila there was $1.073 .1 \mathrm{~mm}$ vs. $842.2 \mathrm{in}$ Autlán. Soil classification and pH are similar.

\begin{tabular}{|l|c|c|}
\hline Locality & Autlán & Tequila \\
\hline Altitude, m.s.n.m. & 500 & 1,200 \\
\hline Temperature $^{\circ} \mathrm{C}$ & 25.2 & 23.2 \\
\hline Precipitation $(\mathrm{mm})^{\text {Soil classification }(\mathrm{mm})}$ & 842.2 & $1,073.1$ \\
\hline pH & Sandy loam & Sandy loam \\
\hline
\end{tabular}

Table 1: Altitude, climate data and soil classification from two locations in Jalisco.

\section{Soil composition}

Table 2 shows the results of the soil analysis of the sampling sites.

\begin{tabular}{|l|c|c|}
\hline Soil Composition & Autlán \% & Tequila \% \\
\hline Organic carbon & $5.09 \pm 0.57$ & $4.35 \pm 0.27$ \\
\hline Nitrogen & $0.24 \pm 0.09$ & $0.22 \pm 0.07$ \\
\hline Organic matter & $2.95 \pm 0.90$ & $2.50 \pm 0.70$ \\
\hline $\mathrm{Mg}$ & $0.27 \pm 0.09$ & $0.27 \pm 0.05$ \\
\hline $\mathrm{Ca}$ & $0.57 \pm 0.11$ & $0.47 \pm 0.06$ \\
\hline $\mathrm{K}$ & $0.38 \pm 0.03$ & $0.73 \pm 0.06$ \\
\hline $\mathrm{P}$ & $0.09 \pm 0.003$ & $0.01 \pm 0.001$ \\
\hline
\end{tabular}

Table 2: Soil analisys (\%). Mean values of triplicate.

Higher content in this parameters is seen in the "Autlán" sampling site with respect to the "Tequila" sampling site, with the exception of content of Mg and K. Nutritional content of samples would be related to the climatic and ethnological conditions, for example, the higher content of organic matter, among other important factors. Organic matter (humus) is directly related to the fertility and productivity of soils and ecosystems, since it participates in biological, chemical and physical processes of the soil such as water infiltration, its retention, aeration, which favors the promotion of root growth, which is important for this type of trees that has a large biomass and volume, but also in [17]. Nitrogen in the soil allows a higher protein content of fruits, seeds and foliage, and can improve the forage palatability [18]. Phosphorus and Potassium would influence the biomass yield, which is favorable, although rapid growth could decrease its quality.

\section{Proximate chemical composition}

The results of the Proximal Chemical Analysis are shown in table 3.

\begin{tabular}{|l|c|c|}
\hline Proximal Chemical Analysis & Autlán & Tequila \\
\hline Moisture & $10.0 \pm 1.46$ & $11.35 \pm 0.64$ \\
\hline Crude Protein (CP) & $30.34 \pm 1.10$ & $19.56 \pm 2.15$ \\
\hline Ether Extract (EE) & $3.22 \pm 0.15$ & $1.98 \pm 0.25$ \\
\hline Crude fiber (CF) & $20.38 \pm 4.61$ & $8.14 \pm 3.16$ \\
\hline Ash & $4.0 \pm 0.36$ & $4.61 \pm 0.24$ \\
\hline Carbohydrates (NFE) & $43.35 \pm 6.45$ & $66.22 \pm 8.54$ \\
\hline
\end{tabular}

Table 3: Proximate analysis results of Enterolobium cyclocarpum seeds from two locations in Jalisco (g/100g dry matter).

A higher concentration of these parameters was found in the seeds of Autlán than in those of Tequila. So, when comparing Autlán against Tequila, Crude CP $30.34 \%$ vs $19.56 \%$, CF $20.38 \%$ vs $8.14 \%$, EE $3.22 \%$ vs $1.98 \%$. The carbohydrates were calculated taken by difference and higher in Tequila $66.22 \%$ vs $43.35 \%$. The ash content was similar for seeds from both localities evaluated, with 4.0$4.61 \%$. Proximate analysis is consistent with the $22.8 \% \mathrm{CP}, 57.3 \%$ NFE and the 3.7\% EE contents: and minor that the $13.27 \% \mathrm{CF}$ found in other investigations over seeds of E. cyclocarpum [4].

Protein found in the seeds of E. cyclocarpum are like to the content in legumes of general consumption such as bean (Phaseolus vulgaris.) of 20.12\% [19]; chick-pea (Cicer arietinum) $26.2 \%$, green pea (Pisum sativum) 21.3\%; and sorghum (Sorghum vulgare) with 6 to $19.6 \%$ [20], but lower than protein value in soybean of $40 \%$. Likewise, Crude fiber, carbohydrates, ether extract and some minerals values are satisfactory. Carbohydrates (NFE) are like those of presents in bean, for example, with 60 - 65\% [8]. Fibers associated with carbohydrates help digestion, are resistant to the hydrolytic action of enzymes, add volume to food, favor the adsorption of water in the digestive tract [8]. In the same way, ether extract values in E. cyclocarpum seeds are comparable to those of other common legumes, such as soybean meal of $1.9 \%$ or faba bean with $0.94 \%$ (21). Lipids constitute the reserve and supply of energy, as well as fatty acids, such as linoleic and linolenic, easily digestible by animals. Lipids represent 2.25 times the energy stored in car- 
bohydrates. Total digestible nutrients values (not reported in this work) are also an important parameter, for example, the reported for beans (61.13 to 65.43\%) [22]. Likewise, E. cyclocarpum seeds from Autlán show the best nutritional properties, because, from the point of view of concentration, it has a higher level of protein, amino acids, and some minerals. This higher nutritional content would be related to the climatic and ethnological conditions of the Autlán sampling site, for example, the higher content of organic matter, among other important factors. We have highlighted the protein content in Parota seeds, since it is the main ingredient in the diet of producer animals, and also in the human diet [23].

\section{Amino acids}

The values determined for the various amino acids found in $E$. cyclocarpum seeds are shown in table 4 [24].

\begin{tabular}{|c|c|c|}
\hline Amino acids & $\begin{array}{c}\text { Autlán }(\mathrm{mg} / \mathrm{g} \\
\text { protein) }\end{array}$ & $\begin{array}{l}\text { Tequila (mg/g } \\
\text { protein) }\end{array}$ \\
\hline \multicolumn{3}{|l|}{ Essential amino acids } \\
\hline $\begin{array}{l}\text { Aromatic amino acids (phe- } \\
\text { nylalanine + tyrosine) }\end{array}$ & $47.9 \pm 0.45$ & $40.5 \pm 0.24$ \\
\hline L-Isoleucine & $46.1 \pm 0.52$ & $35.3 \pm 0.31$ \\
\hline L-leucine & $80.5 \pm 0.43$ & $68.3 \pm 0.72$ \\
\hline Lysine & $70.2 \pm 0.70$ & $59.0 \pm 0.81$ \\
\hline $\begin{array}{l}\text { Sulphured amino acids } \\
\text { (methionine + cysteine) }\end{array}$ & $18.5 \pm 0.57$ & $41.8 \pm 0.98$ \\
\hline Threonine & $31.5 \pm 0.23$ & $39.3 \pm 1.32$ \\
\hline L-valine & $47.2 \pm 0.37$ & $38.2 \pm 0.44$ \\
\hline L-Histidine & $45.4 \pm 0.47$ & $33.2 \pm 0.23$ \\
\hline \multicolumn{3}{|l|}{ No essential amino acids } \\
\hline Aspartic acid & $100.5 \pm 1.33$ & $88.6 \pm 1.22$ \\
\hline Alanin & $45.7 \pm 2.97$ & $43.1 \pm 1.08$ \\
\hline Arginine & $77.6 \pm 0.15$ & $61.7 \pm 1.51$ \\
\hline Glycine & $41.7 \pm 0.69$ & $45.1 \pm 0.84$ \\
\hline L-Serine & $49.3 \pm 0.82$ & $59.4 \pm 0.51$ \\
\hline Total & 702.1 & 653.5 \\
\hline
\end{tabular}

Table 4: Amino acids extracted from Enterolobium cyclocarpum seeds referenced.

Mostly seeds from E. Cyclocarpum from of Autlán place have the highest content, except in sulphured amino acids, threonine and Serine, in which Tequila seeds have a higher content. Legumes are known to have a low content of sulfur amino acids. Generally, seeds of E. cyclocarpum have high content of amino acids, except sulfured, specially methionine and cystine [25].

FAO requirements $(\mathrm{mg} / \mathrm{g} / \mathrm{d}$ ) for school child/adolescent (3 - 10 years old) are covered for nearly all essential amino acids, according to the concentration found for the fruit and seed of E. cyclocarpum. In some cases this standard is exceeded, for example, $\mathrm{L}$. Isoleucine (FAO, $30 \mathrm{mg} / \mathrm{g} / \mathrm{d}$ ), Lysine (FAO, $48 \mathrm{mg} / \mathrm{g} / \mathrm{d}$ ), Threonine (FAO, $30 \mathrm{mg} / \mathrm{g} / \mathrm{d}$ ), and L-Histidine (FAO, $16 \mathrm{mg} / \mathrm{g} / \mathrm{d}$ ).

Seed minerals content

Nitrogen and mineral contents of Enterolobium seeds are presented in table 5 .

\begin{tabular}{|l|c|c|}
\hline Seed minerals & Autlán & Tequila \\
\hline Nitrogen & $2.91 \pm 0.11$ & $2.69 \pm 0.31$ \\
\hline Calcium & $1.58 \pm 0.22$ & $1.35 \pm 0.13$ \\
\hline Potassium & $0.77 \pm 0.08$ & $0.81 \pm 0.02$ \\
\hline Magnesium & $0.32 \pm 0.02$ & $0.29 \pm 0.02$ \\
\hline Sodium & $0.12 \pm 0.04$ & $0.13 \pm 0.06$ \\
\hline Phosphorus & $0.37 \pm 0.07$ & $0.29 \pm 0.05$ \\
\hline Copper & $0.16 \pm 0.09$ & $0.13 \pm 0.07$ \\
\hline
\end{tabular}

Table 5: Element analysis of Enterolobium cyclocarpun seeds ( $\mathrm{g} / 100 \mathrm{~g}$ of dry weight). Value for triplicate.

In both cases, results regarding element contents for the two locations were homogeneous. Compared to Tequila, most results of seeds from Autlán were the same (Calcium, Phosphorus, Cooper values) but different in nitrogen and magnesium with $2.78 \%$ and $0.26 \%$ respectively, probably due to the texture soil quality (morphology, chemistry, acidity) and the mild climate characteristic of the transition forests of this region of Autlan.

In relation to human consumption, these seeds of E. cyclocarpum as a source of protein are within of concentration parameters of essential amino acids, considering as reference the requirements suggested by an authority that regulates these criteria worldwide, such as FAO/WHO. However, to obtain a definitive conclusion, other studies should be done in relation to food consumption. Ethnobotanical experience indicates that seeds are eaten roasted or ground and mixed with different foods, while the green fruits are used in the preparation of soups [26]. In addition, it contains a low content of thermolabile antinutritional factors, so the risks of their consumption are eliminated by boiling them in water [5]. 
The same is true when considering this material for forage use. In view of these results (proximal chemical composition, mainly), an acceptable nutritional content is appreciated, as already discussed above. Complementary data (not made in this study) verify this raw material as a good forage food. It has been reported that the fruit has an in vivo digestibility of $69.47 \%$, which the seed represents $35.6 \%$, the pod $63.1 \%$ and the pedicel $1.25 \%$ [27] Likewise, when feeding sheep with diets of $30 \%$ of grass and concentrations of $0-36 \%$ of parota fruit, a consumption of $5.1 \%$ of live weight dry mass was observed, a weight gain of $229 \mathrm{~g}$ per day and a carcass yield of $49.5 \%$ [28]

Fruits and seeds are used as food in the tropical rural areas of Mexico where this tree is found. The characteristics of E. cyclocarpum produce pasture with good nutritional properties, although the content of saponins could favor methane production in the rumen [29].

\section{Conclusion}

Enterolobium cyclocarpum seeds possess crude protein content comparable a that reported for seeds of other edible legumes such as common bean, chick-pea and green pea. Seeds collected from Autlán showed the best overall characteristics with respect to the organic carbon and nitrogen, probably due to soil acidity and the specific type of soil in these areas. Mineral content of E. cyclocarpum seeds suggests that this legume could be used as an alternative human food source, and a high quality forage for cattle. Seeds collected from the locations near Autlán and Tequila showed good nutrimental characteristics. The nutritional content would be related to the characteristics of the soil of the sampling sites, such as organic matter, available water, minerals. These trees grow preferably in tropical areas. Along with soil factors, this environment, would contribute to the acceptable nutritional values of the seeds of E. cyclocarpum from Autlán closer to the coast, when compared to the seeds of Tequila, site located at a higher altitude and other climatic conditions and soil type. The results found are promising to establish this legume as a source of protein for food or forage, because it contains similar values to other common legumes such as bean, the chick-pea and the green pea. Relative to the amino acid profile, it is similar to that of soy protein, although at lower concentrations.

\section{Conflict of Interest}

None.

\section{Bibliography}

1. Sarukhán J., et al. "Capital natural de México. Síntesis: evaluación del conocimiento y tendencias de cambio, perspectivas de sustentabilidad, capacidades humanas e institucionales". Comisión Nacional para el Conocimiento y Uso de la Biodiversidad, México (2017).

2. Andreu M G., et al. "Enterolobium cyclocarpum, Ear Tree FOR 304". School of Forest Resources and Conservation Department, UF/IFAS Extension (2015).

3. Pennington., et al. "Manual para la identificación en el campo de los principales árboles tropicales de México". INIFAP-FAO. México-Roma (1968.).

4. Alvarez Morales G., et al. "Weight gain, feed conversion and efficiency in sheep fed with parota tree (Enterolobium cyclocarpum) fruit (seed and pod) and poultry manure". Veterinaria México 34.1 (2003): 39-46.

5. Serratos Arevalo J C., et al. “Composición químico-nutricional y de factores antinutricionales en semillas de parota (Enterolobium cyclocarpum)". Interciencia 33 (2008): 850-854.

6. De Luna-Vega A., et al. "Potencial alimenticio animal con harina frutos de parota (Enterolobium cyclocarpum, Jacq.) y capomo (Brosimun alicastrum, Sw)". Revista de Simulación y Laboratorio 4.10 (2017): 13-21.

7. Sabuola F, et al. "Processing and utilization of legumes in the tropics". In Teched. Vital Food and Control Engineering (2012): 3-84.

8. Grela., et al. "Chemical composition of leguminous seeds: part I-content of basic nutrients, amino acids, phytochemical compounds, and antioxidant activity". European Food Research and Technology 243 (2017): 1385-1395.

9. Martinez Pacheco M M., et al. "Enterolobium cyclocarpum (Jacq.) Griseb.: The biotechnological profile of a tropical tree". Boletín Latinoamericano y del Caribe de Plantas Medicinales y Aromáticas 11.5 (2012): 385-399.

10. Gómez Castro H., et al. "Areas con potencial para el establecimiento de árboles forrajeros en el centro de Chiapas". Tecnica Pecuaria en Mexico 44 (2006): 219-230.

11. Galindo J., et al. "Effect of tropical plant foliage on the control of methane production andin vitro ruminal protozoa population". Cuban Journal of Agricultural Science 48.4 (2014): 359364. 
12. Ekanem N J., et al. "Effect of method of preservation on the chemical composition of Enterolobium cyclocarpum leaves". Nigerian Society for Animal Production 47.1 (2020): 246-256.

13. AOAC. "Official methods of analysis of AOAC International". 18th Edition, Revision 4, In: Horwitz W, Latimer G.W. Jr. (eds) AOAC International. Gaithersburg, Maryland, USA (2011).

14. Martinez P., et al. "Enterolobium cyclocarpum (Jacq.) Griseb.: The biotechnological profile of a tropical tree". Boletín Latinoamericano y del Caribe de Plantas Medicinales y Aromáticas 11.5 (2012): 385-399.

15. Urribarrí C L., et al. "Extracción y precipitación de las proteínas solubles del pasto elefante enano (Pennisetum purpureum Schum cv. Mott)". Revista de la Facultad de Agronomía-LUZ 21 (2004): 264-275.

16. Perkin-Elmer. "AY-1-Analysis of Soils: Extractable cations". In The Perkin-Elmer Corporation ed. "Analytical Methods for Atomic Absorption Spectroscopy". Waltham, Massachusetts, USA. 300. AOAC (Association of Official Analytical Chemists, US). (1990).

17. Croswell E T., et al. "The role and function of organic matter in tropical soils". Agroecosystems 61 (2001): 7-18.

18. Rivera D., et al. "Interpreting forage and feed analysis reports". Starkville, MS, USA. Mississippi State University, Extension Service 8 (2010).

19. Ibrahim M., et al. "Forage quality of maize and legumes as monocultures and mixtures at different seed ratios". Journal of Animal and Plant Sciences 22.4 (2012): 987-992.

20. Brestenský M., et al. "The quality of sorghum grain in aspect of utilization amino acids". Journal of Microbiology, Biotechnology and Food Sciences 1 (2012): 1032-1039.

21. Güzel D., et al. "Effect of cooking methods on selected physicochemical and nutritional properties of barlotto bean, chickpea, faba bean, and white kidney bean". Journal of Food Science and Technology 49.1 (2012): 89-95.

22. Abd-El-Salaman, et al. "The impact of corporate image and reputation on service quality, customer satisfaction and customer loyalty: testing the mediating role. Case analysis in an international service company". The Business and Management Review 3.2 (2013).

23. Friedman M., et al. "Nutritional and. Health Benefits of soy protein". Journal of Agricultural and Food Chemistry 49 (2001): 1069-1086.
24. World Health Organization/Food and Agriculture Organization/United Nations University. "Protein and Amino Acid Requirements in Human Nutrition Report of a Joint WHO/FAO/ UNU Expert Consultation. WHO Technical Report Series no. 935. Geneva: WHO (2007)

25. Cecconello G., et al. "Composición química y degradabilidad ruminal de los frutos de algunas especies forrajeras leñosas de un bosque seco tropical". Junio (2009).

26. González C. “Especies vegetales de importancia económica en México". Porrúa Ed. México (1984).

27. Ortiz M A., et al. "Feed value of Enterolobium cyclocarpum fruits for calves". Turrialba, Costa Rica: Centro de Agronomía Tropical de Investigación y Enseñanza Turrialba 39 (1989): 209-214.

28. Moscoso C., et al. "Effects of guanacaste tree (Enterolobium cyclocarpum Jacq. Griseb.) fruit as replacement for sorghum grain and cotton seed meal in lamb Diets". Small Ruminant Research 18 (1995): 121-124.

29. Rodríguez R., et al. "In vitro ruminal fermentation of Pennisetum purpureum CT-115 supplemented with four tropical browse legume species". Animal Feed Science and Technology 151 (2009): 65-74.

\section{Assets from publication with us}

- Prompt Acknowledgement after receiving the article

- Thorough Double blinded peer review

- Rapid Publication

- Issue of Publication Certificate

- High visibility of your Published work

Website: www.actascientific.com/

Submit Article: www.actascientific.com/submission.php

Email us: editor@actascientific.com

Contact us: +919182824667 